\title{
Physical and Biogeochemical Characterization of a Tropical Karstic Marsh in the Yucatan Peninsula, Mexico.
}

Eduardo Cejudo ( $\sim$ eduardo.cejudo@cicy.mx) CONACYT: Consejo Nacional de Ciencia y Tecnologia https://orcid.org/0000-0002-5779-517X Daniela Ortega-Camacho

Centro de Investigación Científica de Yucatán: Centro de Investigacion Cientifica de Yucatan

Eduardo Arturo García-Vargas

Centro de Investigación Científica de Yucatán: Centro de Investigacion Cientifica de Yucatan

Elizabeth Hernández-Alarcón

INECOL: Instituto de Ecologia

\section{Research Article}

Keywords: Ecosystem services, groundwater-fed, hydrochemistry, pore water, sabana

Posted Date: July 9th, 2021

DOI: https://doi.org/10.21203/rs.3.rs-664647/v1

License: @ (i) This work is licensed under a Creative Commons Attribution 4.0 International License.

Read Full License 


\section{Abstract}

Karstic wetlands provide important ecosystem services such as maintenance of hydrological balance, flood regulation, drinking water supply and nutrients cycling. It is important to conserve and maintain karstic wetlands due to its interaction with groundwater systems and its socioeconomic relevance. The objective of this research was to generate base-line knowledge of the microtopography, hydroperiod and biogeochemical characteristics of poorly known tropical karstic marshes by testing two hypotheses, the phreatotrophic nature of tropical karstic marshes, and the alteration of its biogeochemistry by a highway dividing the marsh. The study site is located in the north of the state of Quintana Roo (Mexico), in pseudo-paludal depressions associated to fractures. The water level varied from few centimeters below the ground to more than $100 \mathrm{~cm}$. We demonstrate that the wetland is groundwater-fed with differences among groundwater, interstitial and surface water in almost all parameters measured. The water is calcium bicarbonate type; the main processes occurring are recharge, evaporation and rock dissolution. Our results suggests active denitrification, low phosphates attributed to $\mathrm{Ca}$ - and $\mathrm{Fe} / \mathrm{Al}$-bound $\mathrm{P}$, elevated alkalinity and sulfate reduction due to anaerobic conditions in water and soil. The soil reflect its sedimentary origin, the bulk density is low with very high water retention capacity. We do not have enough evidence of the highway modifying the biogeochemistry or hydrology of the marsh. These karstic wetlands provide important provisioning and supporting ecosystem services that should be studied, acknowledged and maintained.

\section{Introduction}

Wetlands are transitional zones between terrestrial and aquatic ecosystems. They are characterized by the presence of standing water and/or saturated soils for long time during the growing season, a condition that enhances the development of aquatic vegetation and hydric soils (National Research Council 1995; Mitsch and Gosselink 2007). Karst is a term used for characteristic landscapes, landscape features, and phenomena developed in water soluble and porous carbonate rocks on surface and underground (Beltram 2016). While most karst systems are characterized by a lack of integrated surface drainage systems, surface wetlands do occur in karst (White 2002). Some surface karstic wetlands are groundwater-fed and exhibit modern or fossil tufas; whereas other karstic systems are closed basins called sinkholes or dolines (Pipan and Culver 2019), formed at major joints or cracks in the bedrock. Some sinkholes form from the surface enlargement of joints by disolution, others form when underground voids collapse leaving an opening to the surface.

Karstic landscapes and their associated wetlands have important socioeconomic values including maintenance of general hydrological balance and flood regulation, drinking water supply, and water for grazing animals or agriculture. Karstic aquifers and wetland remain a significant source of drinking water all over the world and may play an especially vital role in ensuring adequate water supplies for human communities in generally dry surface landscapes (Beltram 2016, Wilson et al. 2019). 
The Ramsar Convention is an important tool in the protection of karstic wetlands. A total of 130 karstic wetlands comprising more than $105,000 \mathrm{~km}^{2}$ are listed, including poljes, permanent surface water features, large ecoregions, and cave systems. Almost one fourth of all karstic Ramsar sites in the world are designated in the Yucatan Peninsula in Mexico (Beltram 2016). In the state of Quintana Roo (México), it has been identified 2890 karst depressions occupying an area of $1147.05 \mathrm{~km}^{2}$, being uvalas the most abundant and poljes the more extensive (Fragoso-Servón et al. 2014). Sinkhole wetlands are also important, but they have received much less attention (Cejudo and Herrera-Caamal 2019) and we do not know how many they area. Sinkholes and uvalas are present across the entire state, whereas poljes are present mainly in valleys. The complexity of karstic wetlands, their values, and ecosystem services are still not fully recognized. To conserve and maintain karstic wetlands, it is important the knowledge of their main characteristics and understanding of the functioning and processes that form and sustain these ecosystems. Recognizing the interlinkage and interaction of exokarstic structures with groundwater systems, as well as their ecosystem services, is crucial to conserve and sustain wetlands within their catchments.

The aim of this study was to generate base-line knowledge of the physical and biogeochemical characteristics of poorly known tropical karstic marshes, testing two hypotheses: 1) the tropical karstic marshes locally called sabanas are phreatotrophic wetlands, (i.e. groundwater-fed), and 2) the highway dividing the marsh into two sections alters the biogeochemistry of the portions of the marsh.

\section{Materials And Methods}

\section{Study Area}

This research was completed in a tropical karstic marsh located in the community La Esperanza, municipality of Lázaro Cárdenas, state of Quintana Roo (Mexico). The climate is warm sub-humid (Aw), with annual mean temperature of $24.7^{\circ} \mathrm{C}$, and annual mean precipitation of $1249.5 \mathrm{~mm}$ (884-2734.2 mm; 1951-2010 historical records; INEGI 2016). The marsh is located in a pseudo-paludal environment (Fragoso-Servón et al. 2019), the geological setting is a carbonate platform dominated by Neogene and Quaternary sedimentary calcites (INEGI 2009), the soil in the elevated land is mostly Leptsol; however, inside karstic depressions it can be Gleysol (Fragoso-Servón et al. 2017, 2019). Tropical karstic marshes locally named sabanas are common landscapes of the Holbox Fracture Zone, characterized for wetlands established in solution depressions related to faults and fractures (McKay et al. 2020). The marsh (north limit $20.977274^{\circ} \mathrm{N}, 87.418609^{\circ} \mathrm{W}$; south limit $20.964197^{\circ} \mathrm{N},-87.423740^{\circ} \mathrm{W}$ ) is divided by a state highway in two sections, identified as north and south portions. We established two transects in each portion, in order to capture the spatial variability of the marsh and the potential effect of fragmentation upon the biogeochemical characteristics of the marsh (Fig. 1). We estimated the area using a Sentinel-2 image with 0\% cloud cover from January 10th 2019 (Sentinel-2 - Tile: T16QDJ Acquisition Date:07-JAN19 for Scene: L1C_T16QDJ_A009604_ 20190107T161737). The image was further edited in QGIS 3.8.3Zanzibar. The GIS was trained defining wetland and non-wetland areas for a supervised classification 
and vectorization of the polygons. We obtained three main polygons with a total wetland area of $777,385.14 \mathrm{~m}^{2}$. The sampling transects were located in polygons $A$ and $B$.

\section{Microtopography and hydroperiod}

The microtopography of the study site was measured by leveling the microrelief with a mobile arm with a bubble level attached to a $1 \mathrm{~m}^{2}$ aluminum square to determine the difference in height of a cross-section from east to west in polygon A (north of the state highway). This method is an alternative to the level hose previously reported (Flores-Verdugo et al. 2007). The leveling was done with respect to the surrounding-elevated terrain and not respect to the mean sea level. The hydroperiod of the wetland was recorded between the months of October 2019 and November 2020, with PVC pipes (1/2" width) buried $30 \mathrm{~cm}$ into the soil. Measurements in the same site were not completed from September to November 2020 due to disappearance of the pipes form the site (likely stolen); thus, we completed measurement of the water level at random locations inside the marsh.

\section{Soil}

Soil properties were assessed by the edaphic factors gravimetric $(\omega)$ and volumetric water content $(\theta)$, bulk density $\left(D_{a}\right)$, porosity $(P)$ and saturation (S, Campos-Cascaredo and Moreno-Casasola 2009). In eight samples, we analysed ferrous iron $\left(\mathrm{Fe}^{2+}\right)$ by a modification of the method by Heaney and Davison (1977) using a,a-bipyridyl as colorimetric indicator in soil aqueous solutions. This measurement is a proxy of the redox status of the soil, as its presence indicates anoxic soil conditions (Kutzbach et al. 2004). A qualitative analysis of the elemental composition of the soil was performed by X-ray spectroscopy with a scanning electron microscope (SEM) in sub-samples of dry soil. The sample support was a Double-Sided Carbon Tape (Electron Microscopy Sciences ${ }^{\circledR}$ ) so that $C$ and $O$ were detected in the same proportion in all samples; therefore, they were eliminated from the analysis. The SEM conditions for the acquisition of spectra was $35^{\circ}$ elevation of spectrum acquisition, $20.00 \mathrm{kv}$ acceleration, resolution greater than $45 \mathrm{eV}$, with count / variable of spectra. The values express the percentage of each element with respect to the total sample. We assume that the elemental composition would not change significantly during the study period, so we only analysed the samples from October 2019.

\section{Water chemistry}

The physicochemical parameters of surface and pore water were measured at five points in each study site. The temperature $\left({ }^{\circ} \mathrm{C}\right), \mathrm{pH}$, electrical conductivity $(\mathrm{mS} / \mathrm{cm})$ and content of total dissolved solids $(\mathrm{g} / \mathrm{L})$ were measured with a Hanna ${ }^{\circledR}$ Temp / pH / EC / TDS probe (HI98129); while the oxide reduction potential (mv) with a Hanna ${ }^{\circledR}$ ORP / PH H198121 probe. The probes were previously calibrated with buffers and calibration standards. We aimed to collect a total of 20 surface water and 20 interstitial water samples per sampling event; however, water was not available at all sampling points in October 2019 (saturation below $20 \mathrm{~cm}$ from ground surface). All samples were collected at the same points where hydroperiod and physicochemical parameters were measured. Surface water was sampled directly, interstitial water was sampled from $20 \mathrm{~cm}$ deep with a 5/16-inch perforated copper tube hose attached to 
a manual peristaltic pump. The water samples were stored cold (approximately $4{ }^{\circ} \mathrm{C}$ ) in Nalgene ${ }^{\circledR}$ highdensity polyethylene bottles. Within the next $6 \mathrm{~h}$, samples for nutrients and ions were filtered with a 0.45 $\mu \mathrm{m}$ pore size Pall囚 nitrocellulose filter.

Total alkalinity was measured by acid titration. Chemical oxygen demand (COD) was analysed using low range Chemetrix ${ }^{\circledR}$ COD vials (0-150 mg/L) following the ASTM D 1252-06 test method B. Nitrite, ammonium, orthophosphates and silica were quantified with spectrophotometric methods using UV-Vis spectrophotometer. Nitrites were quantified with modifications of the Strickland and Parsons (1972) method, using three milliliters of sample volume and adapting the operating range from 0.01 to $0.5 \mathrm{mg} \mathrm{N}$ $\mathrm{NO}_{2}{ }^{-} / \mathrm{L}$. The ammonium ion $\left(\mathrm{NH}_{4}{ }^{+}\right)$was quantified with the salicylate method (Bower and Holm Hansen

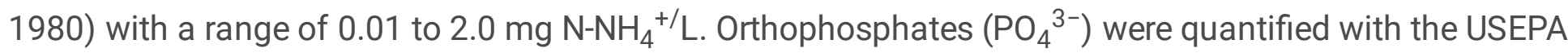

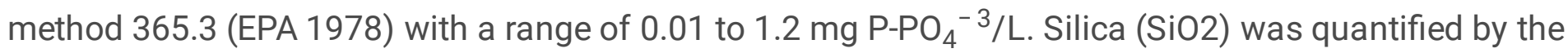
molybdosilicate colorimetric method (NMX-AA-75-1982).

Nitrate and all ions $\left(\mathrm{Cl}^{-}, \mathrm{SO}_{4}{ }^{-2}, \mathrm{Na}^{+}, \mathrm{Mg}^{2+}, \mathrm{K}^{+}, \mathrm{Ca}^{2+}\right)$ were quantified by ion chromatography using an lon Chromatograph $822 \mathrm{IC}$ (Metrohm) with a limit of detection of $0.1 \mathrm{mg} / \mathrm{L}$. Calibration curves were prepared with Fluka and Sigma Aldrich standards; the integration of results was completed using the software MagIC Net. All results were expressed in $\mathrm{mg} / \mathrm{L}$ and meq/L of each chemical species. An ionic balance was carried out to verify the accuracy of ion quantifications.

\section{Hydrochemistry}

Hydrogeochemical relations were explored to find out water-rock interaction processes, and saturation indexes were estimated to identify dissolution or saturation of mineral. Piper, Chadah and Gibbs diagrams were produced to identify the water family and dominant processes in surface and interstitial water, compared with groundwater form two nearby production wells.

\section{Statistical Analyses}

Graphs were made with SPSS 13. In order test our first hypothesis (the phreatotrophic regime of the marsh), we analysed differences between sampling events and water sample origins with two-way ANOVA tests, applying a Tukey HSD post hoc test $(a=0.05)$ for assessing differences in surface, interstitial and groundwater. Once we identified similarities and differences in the three sources of water, we tested our second hypothesis, the effect of the division of the marsh by a highway. We performed twoway ANOVA tests per sampling event (October 2019 and February 2020), for assessing the variability of the parameters by section of the marsh (north and south), and the origin of water samples. In this stage, we compared only surface and interstitial water because we consider that, at this scale, groundwater is regionally stable. Hydrochemistry diagrams were produced with Diagrammes Versión 6.73

\section{Results}

Microtopography and hydroperiod. 
The microtopography of a representative east-west cross-section with the dominant vegetation is showed in Fig. 2. This cross-section of the marsh is located in the north portion of the marsh, it spans $198 \mathrm{~m}$ and the shallowest point from the surrounding uplands was $0.8 \mathrm{~m}$. The steep slopes from 2 to $30 \mathrm{~m}$ (east), and then again from 140 to $160 \mathrm{~m}$ (west), corresponded to rock outcrops, creating step-like sections that remain moist or saturated, with vegetated patches. The water level (Fig. 3) varied from few centimeters below the ground level to more than $100 \mathrm{~cm}$ in November 2020 after the hurricanes Delta and Zeta (October 2020).

\section{Soil}

The properties of the soil (bulk density, gravimetric, volumetric content, porosity and saturation) were different between sampling events $(F=6.368, p=0.016)$ and between the north and south portions of the marsh $(F=14.137, p=0.001)$. The bulk density is low as expected in saturated soils, with a very high gravimetric water content and a volumetric content that reflect the same amount of water and soil in this marsh. Table 1 shows the results.

Table 1

Edaphic and physicochemical parameters of the tropical karstic marsh soil: bulk density $\left(D_{a}\right)$, gravimetric $(\omega)$ and volumetric $(\theta)$ water content, percentage porosity $(P)$ and percentage saturation.

\begin{tabular}{|c|c|c|c|c|c|c|c|}
\hline Event & Portion & & $D_{a}\left(g \mathrm{~cm}^{-3}\right)$ & $\omega\left(g^{-1}\right)$ & $\theta\left(\mathrm{cm} \mathrm{cm}^{-3}\right)$ & $\mathrm{P}(\%)$ & S (\%) \\
\hline \multirow[t]{4}{*}{ October 2019} & $\mathrm{~N}$ & Avg & 0.23 & 5.77 & 1.02 & 91.30 & 111.10 \\
\hline & & s.d. & 0.11 & 3.17 & 0.15 & 4.47 & 14.15 \\
\hline & $S$ & Avg & 0.14 & 7.87 & 1.03 & 94.60 & 109.50 \\
\hline & & s.d. & 0.05 & 2.17 & 0.12 & 1.90 & 13.80 \\
\hline \multirow[t]{4}{*}{ February 2020} & $\mathrm{~N}$ & Avg & 0.42 & 2.95 & 1.06 & 84.20 & 127.20 \\
\hline & & s.d. & 0.20 & 1.11 & 0.08 & 7.32 & 10.50 \\
\hline & S & Avg & 0.19 & 6.73 & 1.05 & 92.90 & 112.90 \\
\hline & & s.d. & 0.08 & 2.92 & 0.06 & 3.00 & 7.16 \\
\hline
\end{tabular}

The quantification of ferrous iron is showed in Table 2. Its quantification assume total extraction of $\mathrm{Fe}^{2+}$ from the soil and it is presented as $\mathrm{mg} \mathrm{Fe}^{2+} / \mathrm{L}$. We noticed that highest concentrations of $\mathrm{Fe}^{2+}$ were found in the south portion of the marsh. The elemental analysis of the samples showed that $\mathrm{Ca}$ is the dominant element, followed by $\mathrm{Si}, \mathrm{Al}$ and $\mathrm{Mg}$, the latter was slightly lower in the north section. The most important differences were the presence of sulfur solely in the south portion, and chloride and iron only in the north portion (Fig. 3). 
Table 2

Ferrous iron $\left(\mathrm{mg} \mathrm{Fe}^{2+} / \mathrm{L}\right)$ from the tropical karstic marsh soil $(n=8)$.

\begin{tabular}{|lll|}
\hline Event & Portion & $\mathrm{Fe}^{2+}(\mathrm{mg} / \mathrm{L}) \pm$ s.d. \\
\hline October 2019 & $\mathrm{N}$ & $0.058 \pm 0.034$ \\
\cline { 2 - 3 } & $\mathrm{S}$ & $0.104 \pm 0.035$ \\
February 2020 & $\mathrm{N}$ & $0.756 \pm 0.355$ \\
& $\mathrm{~S}$ & $0.213 \pm 0.024$ \\
\hline
\end{tabular}

\section{Water}

When exploring the physicochemical parameters by comparing means (and standard deviations) among groundwater (GW), interstitial (IW) and surface water (SW) by sampling event, we noted that almost all parameters had differences between events and among the origin of water samples. In order to test our first hypothesis, we analysed differences between sampling events in the three water samples (surface, interstitial and groundwater). The results are showed in Table 3. We did not observe consistent trends in similarities or differences among groundwater (GW) relative to surface (SW) or interstitial water (IW). For instance, electrical conductivity was similar in GW and IW, possibly because similar amount of dissolved solids, lower in SW due to dilution from rain. pH was similar between GW and SW, more acidic conditions in IW might be attributed to elevated organic acids in the rhizosphere. Moderately reduced condition in GW $(\approx 250 \mathrm{mV})$ but reduced conditions in SW $(\approx 90 \mathrm{mV})$ and IW $(\approx-16 \mathrm{mV})$. Reductive conditions in the rhizosphere (SW and IW) are also supported by low nitrates and sulfates concentration, together with high alkalinity in IW. Mg and Ca were also different (greater in GW and IW), but we interpret these results as the interaction with rock (GW) and precipitation and biogenic carbonates (IW).

After identifying differences among the three types of water, we explored the differences between the two portions of the marsh, relative to dividing the highway as a physical barrier. When comparing the two portions of the marsh only of SW and IW, we found that IW was higher in electrical conductivity, slightly more acidic and with reducing conditions compared to SW. Interestingly; $\mathrm{pH}$ was different by comparing the portions of the marsh, lower in the south. In case of the nutrients, ammonium was greater in IW water, assumed the result of intense organic matter decomposition, but was not different by portions. The DIN had a different trend; it was higher in the surface water in October 2019, the opposite February 2020 (higher in in the interstitial water).

Silica was very variable among samples, but the COD was similar between SW and IW; however, in February 2019 (with higher flood level) we observed higher silica in the north portion, and higher COD in IW. Alkalinity was always higher in IW, not different by portions. The ions were also mainly different by water origin, only chloride was different in February 2020, higher in the south portion. Sulfates were higher in SW in October 2019, but the opposite in February 2020 (SW < IW). Mg and Ca were always 
higher in IW, regardless of the portion. The two-way ANOVA tests results are showed in Table 4 and the complete results are provided in Supplementary Table 1. Box-plot graphs of redox potential (Fig. 5), bicarbonates (Fig. 6), sulfates (Fig. 6) and calcium (Fig. 7) are showed by origin of water, without considering separation by portions of the karstic marsh.

Table 3

Results of the two-way ANOVA test of water by sampling event (October 2019 and February 2020) and origin (groundwater, interstitial and surface water) in the tropical karstic marsh of La Esperanza, Quintana Roo, México. Water samples with different letters (Tukey HSD) were statistically different $(a=0.05)$. n.s = non-significant.

\begin{tabular}{|c|c|c|c|}
\hline Parameter & Sampling event & Origin & Tukey HSD \\
\hline Temperature & $F=6.29, p=0.014$ & n.s. & \\
\hline E.C. & $F=8.397, p=0.005$ & $F=59.287, p<0.001$ & $\mathrm{GW}=\mathrm{IW}^{\mathrm{a}}>\mathrm{SW} \mathrm{b}^{\mathrm{b}}$ \\
\hline $\mathrm{pH}$ & $F=4.402, p=0.04$ & $F=81.97, p<0.001$ & $\mathrm{SW}=\mathrm{GW}^{\mathrm{a}}>\mathrm{I} \mathrm{W}^{\mathrm{b}}$ \\
\hline ORP & $F=16.72, p<0.001$ & $F=64.663, p<0.001$ & $\mathrm{GW}^{\mathrm{a}}>\mathrm{SW}^{\mathrm{b}}>\mathrm{IW}^{\mathrm{c}}$ \\
\hline Nitrites & $F=19.512, p<0.001$ & n.s. & \\
\hline Nitrates & n.s. & $F=4.252, p=0.02$ & $\mathrm{GW}^{\mathrm{a}}>\mathrm{IW}=\mathrm{SW}^{\mathrm{b}}$ \\
\hline Ammonium & $F=5.008, p=0.029$ & n.s. & \\
\hline TP & $F=6.839, p=0.017$ & n.s. & \\
\hline COD & $F=29.098, p<0.001$ & n.s. & \\
\hline Silica & $F=4.844, p=0.031$ & n.s. & \\
\hline Alkalinity & $F=4.019, p=0.049$ & $F=20.286, p<0.001$ & $\mathrm{IW}^{\mathrm{a}}>\mathrm{GW}=\mathrm{SW}^{\mathrm{b}}$ \\
\hline Chloride & $F=14.177, p<0.001$ & n.s. & \\
\hline Sulfates & $F=19.525, p<0.001$ & $F=11.537, p<0.001$ & $\mathrm{GW}^{\mathrm{a}}>\mathrm{IW}=\mathrm{SW} \mathrm{W}^{\mathrm{b}}$ \\
\hline Magnesium & n.s. & $F=20.004, p<0.001$ & $\mathrm{IW}^{\mathrm{a}}>\mathrm{GW}=\mathrm{SW}^{\mathrm{b}}$ \\
\hline Potassium & $F=5.928, p=0.028$ & $F=7.053, p=0.018$ & \\
\hline Calcium & n.s. & $F=16.915, p<0.001$ & $\mathrm{IW}^{\mathrm{a}}=\mathrm{GW} \mathrm{W}^{\mathrm{ab}}=\mathrm{SW}^{\mathrm{b}}$ \\
\hline
\end{tabular}


Table 4

Results of the two-way ANOVA test of water by portions (north and south), and origin (groundwater, interstitial and surface water) in the tropical karstic marsh of La Esperanza, Quintana Roo, México. n.s = non-significant $(a=0.05)$.

\begin{tabular}{|c|c|c|c|}
\hline Parameter & Sampling event & Portion & Origin \\
\hline \multirow[t]{2}{*}{ Temperature } & October 2019 & \multirow[t]{2}{*}{ n.s } & n.s \\
\hline & February 2020 & & $F=4.83, p=0.034$ \\
\hline \multirow[t]{2}{*}{ E.C. } & October 2019 & \multirow[t]{2}{*}{ n.s } & $F=38.47, p<0.001$ \\
\hline & February 2020 & & $F=313.22, p<0.001$ \\
\hline \multirow[t]{2}{*}{$\mathrm{pH}$} & October 2019 & $F=5.64, p=0.025$ & $F=54.34, p<0.001$ \\
\hline & February 2020 & $F=6.34, p=0.016$ & $F=110.7, p<0.001$ \\
\hline \multirow[t]{2}{*}{ ORP } & October 2019 & \multirow[t]{2}{*}{ n.s } & $F=28.2, p<0.001$ \\
\hline & February 2020 & & $F=65.23, p<0.001$ \\
\hline \multirow[t]{2}{*}{ Ammonium } & October 2019 & \multirow[t]{2}{*}{ n.s } & n.s \\
\hline & February 2020 & & $F=9.38, p=0.004$ \\
\hline \multirow[t]{2}{*}{ Phosphates } & October 2019 & \multirow[t]{2}{*}{ n.s } & \multirow[t]{2}{*}{ n.s } \\
\hline & February 2020 & & \\
\hline \multirow[t]{2}{*}{ DIN } & October 2019 & \multirow[t]{2}{*}{ n.s } & $F=5.04, p=0.033$ \\
\hline & February 2020 & & $F=9.25, p=0.004$ \\
\hline \multirow[t]{2}{*}{ COD } & October 2019 & \multirow[t]{2}{*}{ n.s } & n.s \\
\hline & February 2020 & & $F=6.23, p=0.017$ \\
\hline \multirow[t]{2}{*}{ Silica } & October 2019 & n.s & \multirow[t]{2}{*}{ n.s } \\
\hline & February 2020 & $F=4.75, p=0.036$ & \\
\hline \multirow[t]{2}{*}{ Alkalinity } & October 2019 & \multirow[t]{2}{*}{ n.s } & $F=73.79, p<0.001$ \\
\hline & February 2020 & & $F=7.62, p=0.009$ \\
\hline \multirow[t]{2}{*}{ Chloride } & October 2019 & n.s & \multirow[t]{2}{*}{ n.s } \\
\hline & February 2020 & $F=5.074, p=0.030$ & \\
\hline \multirow[t]{2}{*}{ Sulfates } & October 2019 & \multirow[t]{2}{*}{ n.s } & $F=44.93, p<0.001$ \\
\hline & February 2020 & & $F=74.01, p<0.001$ \\
\hline \multirow[t]{2}{*}{ Magnesium } & October 2019 & \multirow[t]{2}{*}{ n.s } & $F=14.53, p<0.001$ \\
\hline & February 2020 & & $F=27.771, p<0.001$ \\
\hline
\end{tabular}




\begin{tabular}{|llll|}
\hline Parameter & Sampling event & Portion & Origin \\
\hline Calcium & October 2019 & n.s & $\mathrm{F}=36.76, \mathrm{p}<0.001$ \\
& February 2020 & & $\mathrm{F}=7.56, \mathrm{p}=0.009$ \\
\hline
\end{tabular}

\section{Hydrochemistry}

The chemical composition of the water is of calcium bicarbonate type, with a chemical composition of cations $\mathrm{Ca}^{2+}>\mathrm{Mg}^{2+} \geq \mathrm{Na}^{+}$. The anions were $\mathrm{HCO}_{3}{ }^{-}>\mathrm{Cl}^{-}>\mathrm{SO}_{4}{ }^{2-}$ (Fig. 8). As a unit, the marsh has a single type of water; however, there are slight differences between SW and IW. The composition of IW appears to be more homogeneous in low flood conditions (October 2019), whereas in high flood conditions (February 2020) its chemical composition was more variable. The most evident increase the $\mathrm{HCO}_{3}{ }^{-}$concentration while $\mathrm{SO}_{4}{ }^{3-}$ has a slight decrease. $\mathrm{GW}$ plots slightly lower in $\mathrm{K}$ but higher in $\mathrm{Na}+$; yet, within the same quadrant than all other samples; suggesting that all the water have the same origin, most likely groundwater.

\section{Saturation index}

The minerals aragonite, calcite and dolomite showed oscillation between saturation and under-saturation, whereas anhydrite, gypsum and halite in both sampling events were under-saturated (Fig. 8). Thus, the dissolution of carbonate rocks is the dominant process in this tropical karstic marsh. Although, it alternates in a very slender threshold depending on the origin of the water (SW or IW) and showed certain temporal variability. The Chadah diagram (Fig. 9) indicates that both SW and IW in both sampling events plot together with GW and both fall into the section of recharge processes. Finally, the Gibbs diagram (Fig. 10) pointed towards two dominant processes, evaporation and rock dissolution.

\section{Discussion}

We accept our hypothesis that tropical karstic marshes locally called sabanas are phreatotrophic wetlands, the hydrochemical data demonstrated that groundwater is the dominant water source in this marsh. Stein et al. (2004) reported that faults may be the conduit responsible for water delivery into wetlands; thus, supporting the assumption of GW provenance for this tropical karstic marsh. The water of the marsh of La Esperanza is calcium bicarbonate type regardless the origin of the sample. We consider that the homogeneous chemical conditions in low flood conditions reflect stable hydraulic conditions, which changed in response to seasonal events (such as frontal rains), the presence of vegetation (Yang et al. 2008) and hydrodynamics (Karstens et al. 2015). It is important to mention that all GW eventually was in the ground surface short after it precipitated, so the SW and IW plotting in the recharge section of the Chadah diagram is attributed to the transit of water from the surface to the vadose zone and the into the shallow aquifer. The water moving through the vadose zone into the saturated zone, interacts with sedimentary rock, dissolving carbonates and as $\mathrm{HCO}_{3}{ }^{-}$and $\mathrm{Ca}^{2+}$ (Ravikumar et al. 2017) as showed by 
the saturation indexes. IW has a more defined chemical composition, the carbonate minerals are around equilibrium, but it also acquired characteristics of infiltrating water that has passed through the soil, such as acidic $\mathrm{pH}$, reductive conditions and organic matter decomposition (Craft et al. 1991). Similar electrical conductivity in GW and IW is assumed as comparable amount of dissolved solids was found in those compartments; the former due to the water-rock interaction (Smith et al. 2020), the latter due to the solubilisation of several substances around the rhizosphere (Raghavendra et al. 2016). In summary, this marsh is a good site to evaluate in detail the water infiltration process and the chemical changes that occur in the water during this process.

Changes in EC in SW are interpreted as entrance of precipitation with the consequent dilution effect in the previously existent surface water (McDonough et al. 2020). Slightly more acidic pH in IW might be attributed to elevated organic acids and secreted substances by organisms in the rhizosphere (Lynch et al. 2012). The water oxidation-reduction potential, together with the behaviour of redox-sensitive species and ferrous iron in the soil, give additional hints of the most probable processes occurring inside the marsh. For instance, moderately reduced condition in $\mathrm{GW}(\approx 250 \mathrm{mV})$ enable nitrates and sulfates presence in $\mathrm{GW}$; whereas reduced conditions in SW $(\approx 90 \mathrm{mV})$ and IW $(\approx-16 \mathrm{mV})$ indicate that most nitrate has been reduced, supported by very low $\mathrm{N}^{-N}{ }_{3}{ }^{-} / \mathrm{L}$ concentrations measured in SW and IW (Close et al. 2016). In addition, ammonium concentrations increase in SW and IW because of organic matter decay, mineralization, retaining or transformation of $\mathrm{NH}_{4}{ }^{+}$(Gribsholt et al. 2006). Ammonia could also be a product of nitrogen fixation, since high nitrogen fixation (expressed as nitrogenase activity) has been described in karstic marshes (Rejmánková and Komárková 2000). DIN in low flood conditions (October 2019) was higher in SW, but changed to higher DIN in IW with greater flood conditions (February 2020). We are not able to estimate $\mathrm{N}$ transformation rates; however, we consider that high DIN in SW is the result of water evaporation from the marsh, yielding greater concentration of $\mathrm{N}$ in a reduced water volume. The water saturated, anoxic soil supported by the ferrous iron tests in soil, provides evidence of reductive conditions in the rhizosphere, which allowed sulphate reduction; thus, promoting high alkalinity in IW (Norton et al. 1988, Pester et al. 2012). To the best of our knowledge, high alkalinity ( $\geq 10 \mathrm{mM} \mathrm{HCO}^{3-}$ ) can inhibit growth of some plants (Cartmill et al. 2008); the alkalinity in this marsh was around $6.2( \pm 2.4$ $\mathrm{mM} \mathrm{HCO}^{3-}$ ) and did not seem to affect the growth of grasses and sedges. High alkalinity in wetlands has been identified as a sink of atmospheric $\mathrm{CO}_{2}$ (Saderne et al. 2021) accounting for an overlooked component of the $\mathrm{C}$ cycle and storage in wetlands.

Low phosphates concentrations in karstic ecosystems is attributed to $\mathrm{Ca}$ - and $\mathrm{Fe} / \mathrm{Al}$-bound $\mathrm{P}$, as they vary spatially and seasonally (Gao et al. 2019). With the measured pH-Eh, the expected $\mathrm{P}$ species is $\mathrm{H}_{2} \mathrm{PO}_{4}{ }^{-}$ (di-hydrogen phosphate ion, Takeno 2005). With oxygen deficiency and stagnant conditions, phosphorus can be released back from sediments to the water column and with oscillating flood conditions; sediments rich in Fe and $\mathrm{Mn}$ are capable of becoming sinks again (Karstens et al. 2015).

The similar COD between SW and IW reveals that with stable hydraulic conditions, the water in the rhizosphere and above the ground had similar amount of organic matter. This situation changed in 
February 2019 (higher flood level), when higher COD in IW indicated increase in dissolved organic matter in the rhizosphere. High COD has also been associated to elevated sulfate reduction and inhibition of some trophic groups by $\mathrm{H}_{2} \mathrm{~S}$ (Barber and Stuckey 2000). This situation was likely occurring in the karst marsh as low sulfate concentrations were measured with high flood. High COD/N ratio (600 to 1800 in La Esperanza marsh) relates to very active denitrifiers, yielding the low nitrate conditions observed, due to high availability of organic matter as electron donor (Hou et al. 2018).

In case of silica, its variable concentration can be related to the hydrology of the marsh and the dominant plant species. Both Grasses (Poaceae) and sedges (Cyperaceae) are Si-accumulating species (Struyf and Conley, 2009) which can release it back to the environment after biomass decay. Marshes are recognized as silica recyclers and re-suppliers (Struyf et al. 2005). We do not know microalgae Si demand, but it is reported that some microalgae can regulate fluxes and DSi concentrations in aquatic environments for as long as six months (Sigmon and Cahoon, 1997). We cannot provide plausible explanations because we ignore the microalgae composition. The knowledge of Si cycling in wetlands is incomplete (Struyf et al. 2005); this topic requires further research, especially due to the relevance of Si as groundwater tracer.

The under-saturation of the evaporitic minerals (anhydrite, gypsum and halite) suggest that those rocks are not dominant underlying this marsh; however, the trend might be opposite in southern areas of the Holbox Fracture system, where other geological formations are dominated by gypsum (Perry et al. 2002). Aragonite, calcite and dolomite had variable trends, there might exists precipitation, deposition and resuspension of biogenic carbonates (Morse 1986) as observed for the variability in saturation indexes between sampling events. The Chadah diagram clearly points towards recharge processes. Additionally, the Gibbs diagram associates some water samples with rock dissolution. Rainwater is the main entrance of water into the aquifer, large part of the precipitation rapidly infiltrates until reaching the saturated zone of the aquifer (Lases-Hernandez et al. 2019). Then, as the phreatic level rises because of increases in the hydraulic head, the GW already in contact with sedimentary rock, increases its interaction with calcite and dolomite, enhancing water erosion (Dai et al. 2017), increasing the dissolved solids in IW and even in SW as the water table elevates above the ground level. Finally, as indicated by the Gibbs diagram, evaporation is another dominant process in the marsh. This evaporation is supported by the increase in dissolved solid in SW during low flood conditions. It is important to mention that, what we consider SW, is a combination of groundwater discharged into the marsh (Gondwe et al. 2010) in addition to intercepted precipitation inside the marsh; thus, the evaporation process affects $S W$ after the combination of the two main processes above-mentioned, yielding water subject to evaporation and rock dissolution.

Regarding our second hypothesis, we have less evidence that the highway had an influence on some parameters in the marsh. For instance, ferrous iron is soil was present in both portions, with higher concentration in the south portion, suggesting prolonged or predominant anoxic conditions. Nonetheless, $\mathrm{X}$-ray spectroscopy suggested that iron (and chloride) were present only in the north portion. This last piece of evidence could be inferred as the effect of surface runoff form the highway. Road traffic has been related to the production and deposition of dust with metals and elements related to engine combustion and tires wear (Adachi and Tainosho 2004, Aguilera et al. 2018). The production of these 
residues, together with the preferential flow northward of the water (Perry et al. 2002, McKay et al. 2020), help explaining its presence only in one side of the road, partially supporting our hypothesis that the highway caused changes in the biogeochemistry of the marsh. We were not able to find effects of the highway in the hydrology of the marsh, the similar flood level in both sides of the road suggest that there is not any apparent hydraulic cut so far. We cannot discuss the fact that the largest polygon located at the north of the highway has something to do with changes in the groundwater flow, discharge or changes in the microtopography.

The soil of this tropical karstic marsh has very high water retention capacity, holding as much as seven grams of water per gram of soil. This condition is not exclusive of marshes; it is a common feature across all types of wetlands (Campos et al. 2011). The soil in these marshes do not develop deep profiles (Fragoso-Servón et al. 2020). Assuming that the mean soil depth in the marsh is $50 \mathrm{~cm}$, with an average apparent density of $0.25 \mathrm{~g} \mathrm{~m}^{-3}\left(250 \mathrm{~kg} \mathrm{~m}^{-3}\right)$, there are approximately $97,173,142.5 \mathrm{~kg}$ of soil in the marsh with an average gravimetric water capacity of $5.8 \mathrm{~kg}$ of water per $\mathrm{kg}$ of soil. This represents an estimated water retention capacity in the soil of this marsh of $563,604 \mathrm{~m}^{3}$ of water (563.6 million liters). When the water column is above the ground such as in November 2020 ( $1 \mathrm{~m}$ flood lever after Hurricanes Delta and Zeta), the micro-basin of this karstic wetland would store at least $700,000 \mathrm{~m}^{3}$ of surface water, in addition to the water stored in the soil. This goes to show the magnitude and relevance of the provisioning and supporting services that tropical karstic marshes provide just by existing, and the importance of maintaining in good conditions for keeping these environmental services, commonly acknowledged but barely understood and quantified (Shepard et al. 2011).

The elemental composition of the soil clearly reflect its sedimentary origin, with calcium as the element comprising $90 \%$ of the mineral fraction. The presence of Si and $\mathrm{Mg}$ are also result of rock weathering (Cejudo et al. 2020). In case of Al, kaolinite is naturally present in young and intermediate karstic landscapes (Bautista et al. 2011) and it is commonly in aluminosilicates and oxide minerals. Its availability do not depend of the redox potential of the environment and is one of the most prevalent contaminants directly attributed to human activities and potentially toxic to aquatic biota (Gensemer and Playle, 1999). Its deposition in the soil is considered result of weathering and mobilization of clays (Cabadas et al. 2010). This element and Si deserves much more attention in wetlands biogeochemistry.

\section{Conclusions}

The tropical karstic marshes of the Yucatan peninsula called sabanas are groundwater-fed wetlands in which reductive conditions regulate processes such as denitrification, sulfate reduction, alkalinity production, high organic matter and elevated content of minerals from sedimentary rock dissolution. Low $\mathrm{PO}_{4}{ }^{3-}$ concentrations are attributed to $\mathrm{Ca}$-bound $\mathrm{P}$ deposited in sediments. The hydrochemical diagrams showed recharge processes together with evaporation and rock dissolution. This means that precipitation infiltrates into the phreatic aquifer (i.e. groundwater recharge). Once the water table elevates above the ground level, it controls the hydroperiod and hydrodynamic of the marsh, showing the water-rock 
interaction of the discharged groundwater, in which there is evaporation of the water exposed at the surface. This marsh is a good site for studying infiltration and recharge processes, as well as the chemical changes occurring to water as it recharges local aquifers. We did not find a negative effect of the highway on the hydrology of the marsh. This marsh provides important provisioning and supporting ecosystemic services as it can store of $563,604 \mathrm{~m}^{3}$ of water in the soil and around $700,000 \mathrm{~m}^{3}$ of surface water; in addition to intense nutrient cycling $(\mathrm{N}$ and $\mathrm{P})$, likely with effective $\mathrm{N}$ removal. The $\mathrm{Si}$ and $\mathrm{Al}$ cycles deserves much more attention in tropical wetlands.

\section{Declarations}

Funding: Project Cátedras CONACYT 2944 "Modelación del ciclo del agua en la península de Yucatán". Project CONAGUA 37001 "Atlas de los humedales del sur - sureste y sus amenazas"

Conflicts of interest: The authors declare that they do not have any conflict of interests

Data availability: The dataset generated and analyzed during the current study is available in the [Institutional Repository $\mathrm{ClCY}$ ] upon acceptance.

Code availability: Not applicable

Author contributions: Conceptualization, Methodology: Eduardo Cejudo, Eduardo A. Garcia Vargas; Formal analysis and investigation: Eduardo Cejudo, Daniela Ortega; Writing - original draft preparation: Eduardo Cejudo, Elizabeth Hernandez; Resources: Eduardo Cejudo.

Additional declarations for articles in life science journals that report the results of studies involving humans and/or animals: Not applicable

Ethics approval: Not applicable

Consent to participate: Not applicable

Consent for publication: Not applicable

\section{References}

1. Adachi K, Tainosho Y (2004) Characterization of heavy metal particles embedded in tire dust. Environ Int 30(8):1009-1017

2. Aguilera A, Armendariz C, Patricia Quintana P, García-Oliva F, Bautista F (2018) Influence of Land Use and Road Type on the Elemental composition of Urban Dust in a Mexican Metropolitan Area. Pol J Environ Stud Volume 28(3):1535-1547

3. Barber WP, Stuckey DC (2000) Effect of sulfate reduction on chemical oxygen demand removal in an anaerobic baffled reactor. Water Environ Res 72(5):593-601 
4. Bautista F, Palacio-Aponte G, Quintana P, Zinck JA (2011) Spatial distribution and development of soils in tropical karst areas from the Peninsula of Yucatan, Mexico. Geomorphology 135(3-4):308321

5. Beltram (2016) Karst Wetlands. In Finlayson C.M.,Everard, M., Irvine, K., Robert J. Mclnnes R.J., Middleton, B.A., van Dam A.A., Davidson N.C. (Eds.). The wetland Book. Springer Science+Business Media Dordrecht. DOI 10.1007/978-94-007-6173-5\$4203-1

6. Bower CE, Holm-Hansen T (1980) A salicylate-hypochlorite method for determining ammonia in seawater. Can J Fish Aquat Sci 37(5):794-798

7. Cabadas HV, Solleiro E, Sedov S, Pi T, Alcalá JR (2010) The complex genesis of red soils in Peninsula de Yucatan, Mexico: mineralogical, micromorphological and geochemical proxies. Eurasian soil science 43(13):1439-1457

8. Campos C, Hernández A, Moreno-Casasola ME, Cejudo Espinosa P, Robledo E R, A. and Mata I, D (2011) Soil water retention and carbon pools in tropical forested wetlands and marshes of the Gulf of Mexico. Hydrol Sci J 56(8):1388-1406

9. Campos-Cascaredo A, Moreno-Casasola P (2009) Suelos hidromorfos. In: Moreno-Casasola P, Warner B (eds) Breviario para describir, observar y manejar humedales. Serie Costa Sustentable no 1. RAMSAR, Instituto de Ecología. CONANP, US Fish and Wildlife Service, US State Department. Xalapa, Ver. México, pp 111-130

10. Cartmill AD, Valdez-Aguilar LA, Bryan DL, Alarcón A (2008) Arbuscular mycorrhizal fungi enhance tolerance of Vinca to high alkalinity in irrigation water. Sci Hortic 115(3):275-284

11. Cejudo E, Acosta-González G, Ortega-Camacho D, Tun-Rosado GE (2020) Changes in the hydrochemistry of a karstic lake in Yucatan, Mexico. Environ Earth Sci 79(5):1-13

12. Cejudo E, Herrera-Caamal (2019) Sinkhole wetlands of the north of Quintana Roo, Mexico: ecosystems barely known. Ecosist Recur Agropec 6(17):207-218,2019

13. Close ME, Abraham P, Humphries B, Lilburne L, Cuthill T, Wilson S (2016) Predicting groundwater redox status on a regional scale using linear discriminant analysis. J Contam Hydrol 191:19-32

14. Craft CB, Seneca ED, Broome SW (1991) Porewater chemistry of natural and created marsh soils. J Exp Mar Biol Ecol 152(2):187-200

15. Dai Q, Peng X, Yang Z, Zhao L (2017) Runoff and erosion processes on bare slopes in the karst rocky desertification area. Catena 152:218-226

16. EPA.1978. Method 365.3: Phosphorous, All Forms (Colorimetric, Ascorbic Acid, Two Reagent). https://www.epa.gov/sites/production/files/2015-08/documents/method_365-3_1978.pdf

17. Flores-Verdugo F, Moreno-Casasola P, Agraz-Hernández CM, López-Rosas H, Benítez-Pardo D, Travieso-Bello AC (2007) Topography and hydroperiod: two factors affecting coastal wetland restoration. Botanical Sciences, (80S), 33-47. https://doi.org/10.17129/botsci.1755

18. Fragoso-Servón P, Bautista F, Frausto O, Pereira. A.2014. Caracterización de las depresiones kársticas (forma, tamaño y densidad) a escala 1:50,000 y sus tipos de inundación en el Estado de Quintana Roo, México. Revista Mexicana de Ciencias Geológicas v. 31:127-137 
19. Fragoso-Servón P, Pereira Corona A, Bautista Zúñiga F, Buenfil Z, G.D.J (2017) Digital soil map of Quintana Roo, Mexico. Journal of maps 13(2):449-456

20. Fragoso-Servón P, Pereira Corona A, Bautista Zúñiga F, Prezas Hernández B, Reyes NA (2020) Soils in extreme conditions: the case of the catenas karst-marsh-coastline. in the Mexican Caribbean: Boletín de la Sociedad Geológica Mexicana 72(2):A040619.

http://dx.doi.org/10.18268/BSGM2020v72n2a040619

21. Fragoso-Servón P, Pereira-Corona A, Bautista F (2019) The Karst and its neighbors: digital map of geomorphic environments in Quintana Roo, Mexico. Journal of Cave \& Karst Studies, 81(2)

22. Gao P, Liu Y, Wang Y, Liu X, Wang Z, Ma LQ (2019) Spatial and temporal changes of $P$ and Ca distribution and fractionation in soil and sediment in a karst farmland-wetland system. Chemosphere 220:644-650

23. Gensemer RW, Playle RC (1999) The bioavailability and toxicity of aluminum in aquatic environments. Crit Rev Environ Sci Technol 29(4):315-450

24. Gondwe BR, Lerer S, Stisen S, Marín L, Rebolledo-Vieyra M, Merediz-Alonso G, Bauer-Gottwein P (2010) Hydrogeology of the south-eastern Yucatan Peninsula: new insights from water level measurements, geochemistry, geophysics and remote sensing. J Hydrol 389(1-2):1-17

25. Gribsholt B, Struyf E, Tramper A, Andersson MG, Brion N, De Brabandere L, Van Damme S, Meire P, Middelburg JJ, Dehairs F, Boschker HT (2006) Ammonium transformation in a nitrogen-rich tidal freshwater marsh. Biogeochemistry 80(3):289-298

26. Heaney SI, Davison W (1977) The determination of ferrous iron in natural waters with 2, 2' bipyridyl. Limnol Oceanogr 22(4):753-760. https://doi.org/10.4319/lo.1977.22.4.0753

27. Hou J, Wang X, Wang J, Xia L, Zhang Y, Li D, Ma X (2018) Pathway governing nitrogen removal in artificially aerated constructed wetlands: impact of aeration mode and influent chemical oxygen demand to nitrogen ratios, 257. Bioresource technology, pp 137-146

28. INEGI (2009) Prontuario de Información Geográfica Municipal de los Estados Unidos Mexicanos. Instituto Nacional de Estadística y Geografía. México.

http://www3.inegi.org.mx/contenidos/app/mexicocifras/datosgeograficos/31/31096.pdf. Date consulted: 22 march, 2021

29. INEGI 2016. Anuario estadístico y geográfico de Quintana Roo 2016. México. 407 p

30. Karstens S, Buczko U, Glatzel S (2015) Phosphorus storage and mobilization in coastal Phragmites wetlands: Influence of local-scale hydrodynamics. Estuarine, Coastal and Shelf Science, 164,124133

31. Kutzbach L, Wagner D, Pfeiffer EM (2004) Effect of microrelief and vegetation on methane emission from wet polygonal tundra, Lena Delta. Northern Siberia Biogeochemistry 69(3):341-362. https://doi.org/10.1023/B:BIOG.0000031053.81520.db

32. Lases-Hernandez F, Medina-Elizalde M, Burns S, DeCesare M (2019) Long-term monitoring of drip water and groundwater stable isotopic variability in the Yucatán Peninsula: Implications for recharge and speleothem rainfall reconstruction. Geochim Cosmochim Acta 246:41-59 
33. Lynch JM, Brimecombe MJ, De Leij FA (2012) Rhizosphere. eLS. John Wiley \& Sons, https://doi.org/10.1002/9780470015902.a0000403.pub2

34. McDonough LK, O’Carroll DM, Meredith K, Andersen MS, Brügger C, Huang H, Rutlidge H, Behnke MI, Spencer RG, McKenna A, Marjo CE (2020) Changes in groundwater dissolved organic matter character in a coastal sand aquifer due to rainfall recharge, 169. Water research, p 115201

35. McKay J, Lenczewski M, Leal-Bautista RM (2020) Characterization of Flowpath Using Geochemistry and 87Sr/86Sr Isotope Ratios in the Yalahau Region, Yucatan Peninsula, Mexico. Water, 12(9), p.2587

36. Mitsch WJ, Gosselink JG (2007) Wetlands, 4th edn. John Wiley \& Sons, New York, 582 pp

37. Morse JW, Arvidson RS, Lüttge A (2007) Calcium carbonate formation and dissolution. Chemical reviews 107(2):342-381. https://doi.org/10.1016/0304-4203(86)90068-X

38. National Research Council (1995) Wetlands: Characteristics and boundaries. National Academies Press, Washington, D.C., p 308

39. NMX-AA-75-1982. Analisis de agua- determinacion de sílice. http://legismex.mty.itesm.mx/normas/aa/aa075.pdf

40. Norton SA, Mitchell MJ, Kahl JS, Brewer GF (1988) In-lake alkalinity generation by sulfate reduction: A paleolimnological assessment. Water Air Soil Pollution 39(1):33-45

41. Perry E, Velazquez-Oliman G, Marin L (2002) The hydrogeochemistry of the karst aquifer system of the northern Yucatan Peninsula, Mexico. Int Geol Rev 44(3):191-221

42. Pester M, Knorr KH, Friedrich MW, Wagner M, Loy A (2012) Sulfate-reducing microorganisms in wetlands - fameless actors in carbon cycling and climate change. Frontiers in microbiology 3:72. https://doi.org/10.3389/fmicb.2012.00072

43. Pipan T, Culver DC (2019) Wetlands in cave and karst regions. Cp 135 In White W.B., Culver, D.C., Pipan,T. (Eds).Encyclopedia of Caves (Third Edition). Pages 1156-1164. https://doi.org/10.1016/B978-0-12-814124-3.00135-7

44. Raghavendra MP, Nayaka SC, Nuthan BR (2016) Role of rhizosphere microflora in potassium solubilization. In: Potassium solubilizing microorganisms for sustainable agriculture. Springer, New Delhi, pp 43-59

45. Ravikumar P, Somashekar RK (2017) Principal component analysis and hydrochemical facies characterization to evaluate groundwater quality in Varahi river basin, Karnataka state, India. Appl Water Sci 7:745-755. https://doi.org/10.1007/s13201-015-0287-x

46. Rejmánková E, Komárková J (2000) A function of cyanobacterial mats in phosphorus-limited tropical wetlands. Hydrobiologia 431(2):135-153

47. Saderne V, Fusi M, Thomson T, Dunne A, Mahmud F, Roth F, Carvalho S, Duarte CM (2021) Total alkalinity production in a mangrove ecosystem reveals an overlooked Blue Carbon component. Limnology Oceanography Letters 6(2):61-67 
48. Shepard CC, Crain CM, Beck MW (2011) The protective role of coastal marshes: a systematic review and meta-analysis. PloS one 6(11):e27374

49. Sigmon DE, Cahoon LB (1997) Comparative effects of benthic microalgae and phytoplankton on dissolved silica fluxes. Aquat Microb Ecol 13(3):275-284

50. Smith DN, Ortega-Camacho D, Acosta-González G, Leal-Bautista RM, Fox WE III, Cejudo E (2020) A multi-approach assessment of land use effects on groundwater quality in a karstic aquifer. Heliyon 6(5):.e03970

51. Stein ED, Mattson M, Fetscher AE, Halama KJ (2004) Influence of geologic setting on slope wetland hydrodynamics. Wetlands 24:244-260. https://doi.org/10.1672/0277-

5212(2004)024[0244:IOGSOS]2.0.C0;2

52. Strickland JDH, Parsons TR (1972) A practical handbook of seawater analysis. Fisheries Research Board of Canada. Ottawa

53. Struyf E, Conley DJ (2009) Silica: an essential nutrient in wetland biogeochemistry. Front Ecol Environ 7(2):88-94

54. Struyf E, Van Damme S, Gribsholt B, Meire P (2005) Freshwater marshes as dissolved silica recyclers in an estuarine environment (Schelde estuary, Belgium). Hydrobiologia 540(1):69-77

55. Takeno N (2005) Atlas of Eh-pH diagrams. Geological survey of Japan open file report 419:102

56. White JB (2002) Karst hydrology: recent developments and open questions. Eng Geol 65:85-105

57. Wilson BJ, Servais S, Charles SP, Mazzei V, Kominoski JS, Gaiser E, Richards J, Troxler T (2019) Phosphorus alleviation of salinity stress: effects of saltwater intrusion on an Everglades freshwater peat marsh. Ecology 100(5):e02672. https://doi.org/10.1002/ecy.2672

58. Yang SL, Li H, Ysebaert T, Bouma TJ, Zhang WX, Wang YY, Li P, Li M, Ding PX (2008) Spatial and temporal variations in sediment grain size in tidal wetlands, Yangtze Delta: on the role of physical and biotic controls. Estuarine, Coastal and Shelf Science, 77(4), 657-671

\section{Figures}




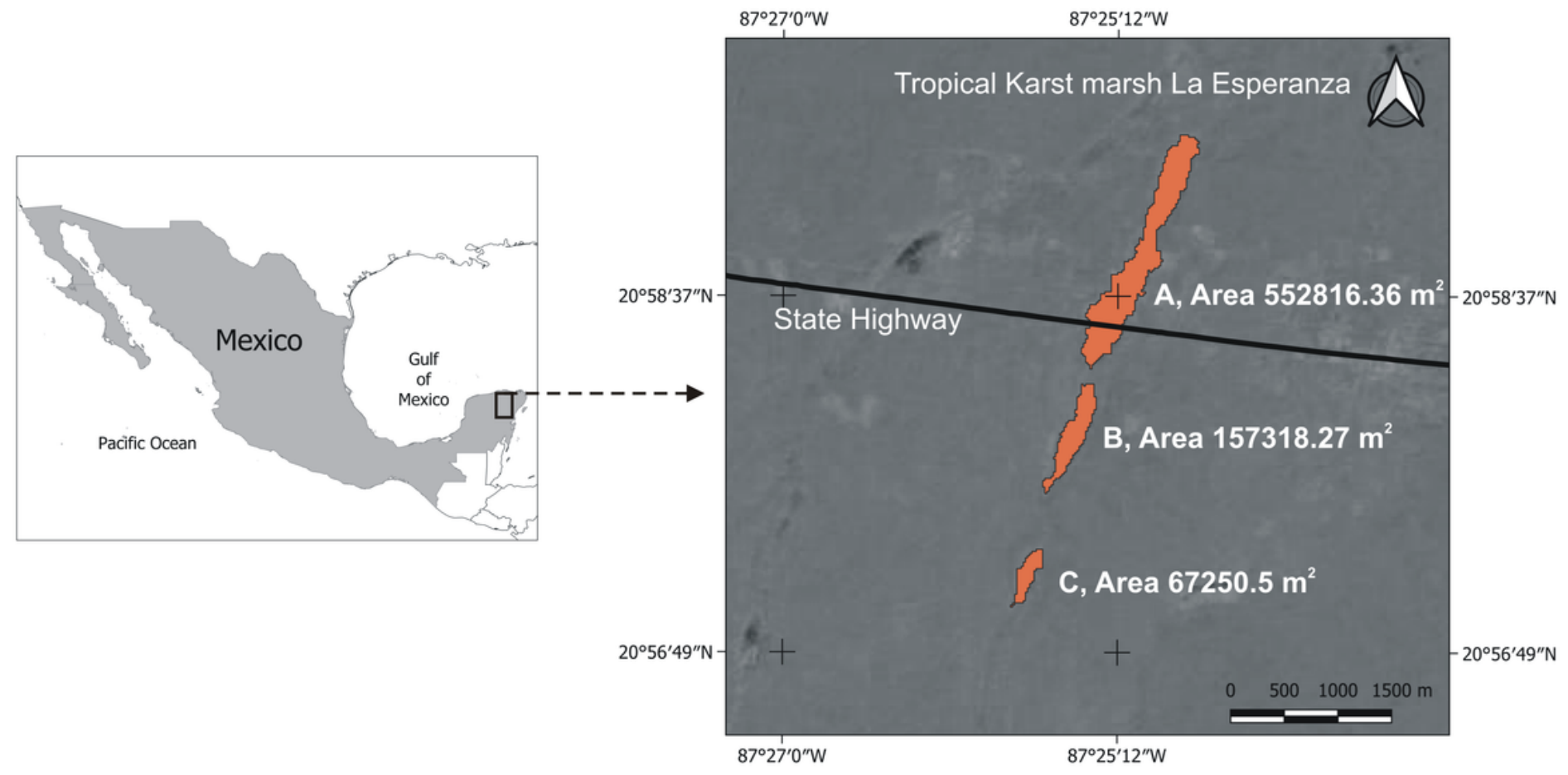

\section{Figure 1}

Study site, tropical karstic marsh “La Esperanza”, Quintana Roo, Mexico

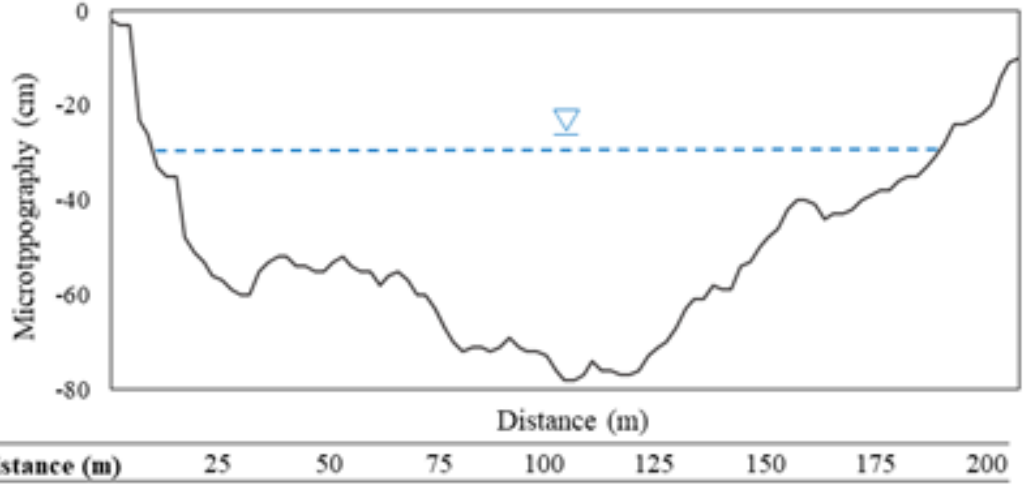

Species

Eleocharis celullosa Torr

Sagittarialancifolia $\mathrm{L}$.

Cladium jamaicense Crantz

R/nnchospora colorata (L.) H. Pfeiff.

Ludvigia bonariensis (Micheli) H.Hara

Ceratophyllum demersum $\mathrm{L}$.

Lippia graveolens Kunth

Persicaria segetum (Kunth) Small

Acoelorraphe wrightii (Griseb. \& H.

Wendl.)

Haematoxylun campechianum $\mathrm{L}$.

Crescentia cujete L.

Figure 2 
Microtopography and dominant vegetation from an east-west cross-section in the tropical karstic marsh of La Esperanza, Quintana Roo, Mexico. Shaded areas represent $25 \mathrm{~m}$ sections with dominant plant species

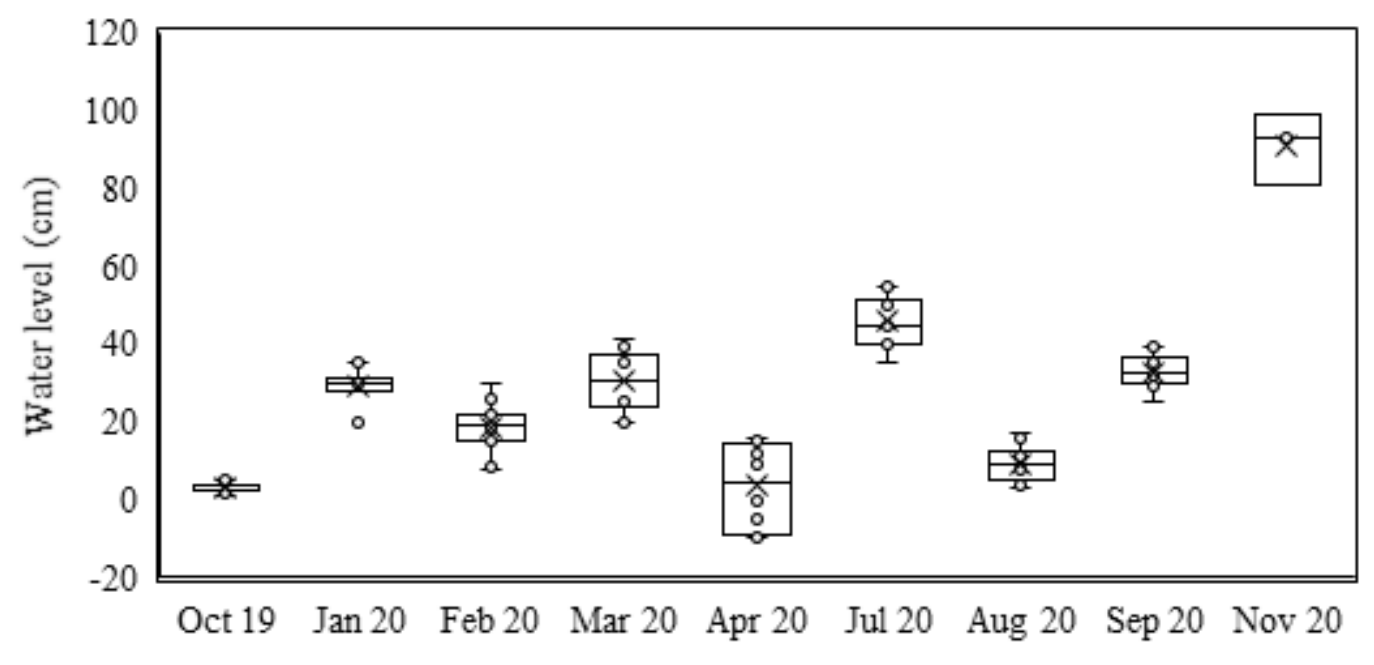

Figure 3

Hydroperiod of the tropical karstic marsh of La Esperanza, Quintana Roo, Mexico. Hurricanes Delta (October 7th) and Zeta (October 27th)

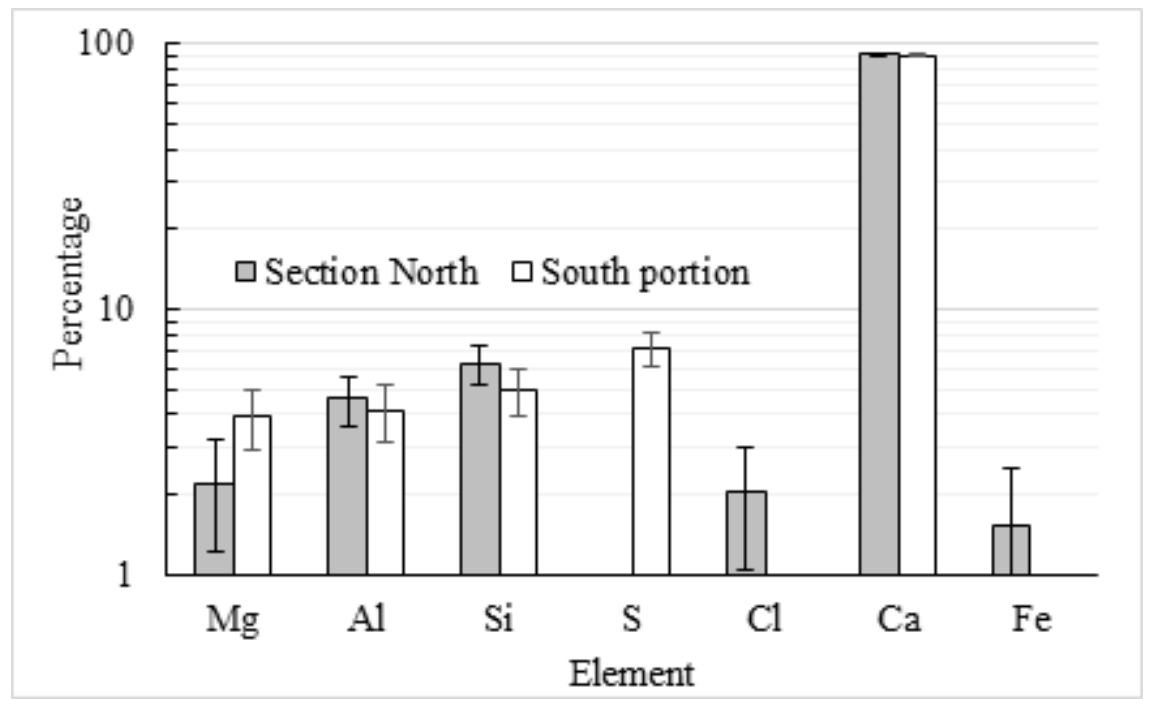

Figure 4

Elemental composition of soil by X-ray spectroscopy measured from the tropical karstic marsh of La Esperanza, Quintana Roo, México 


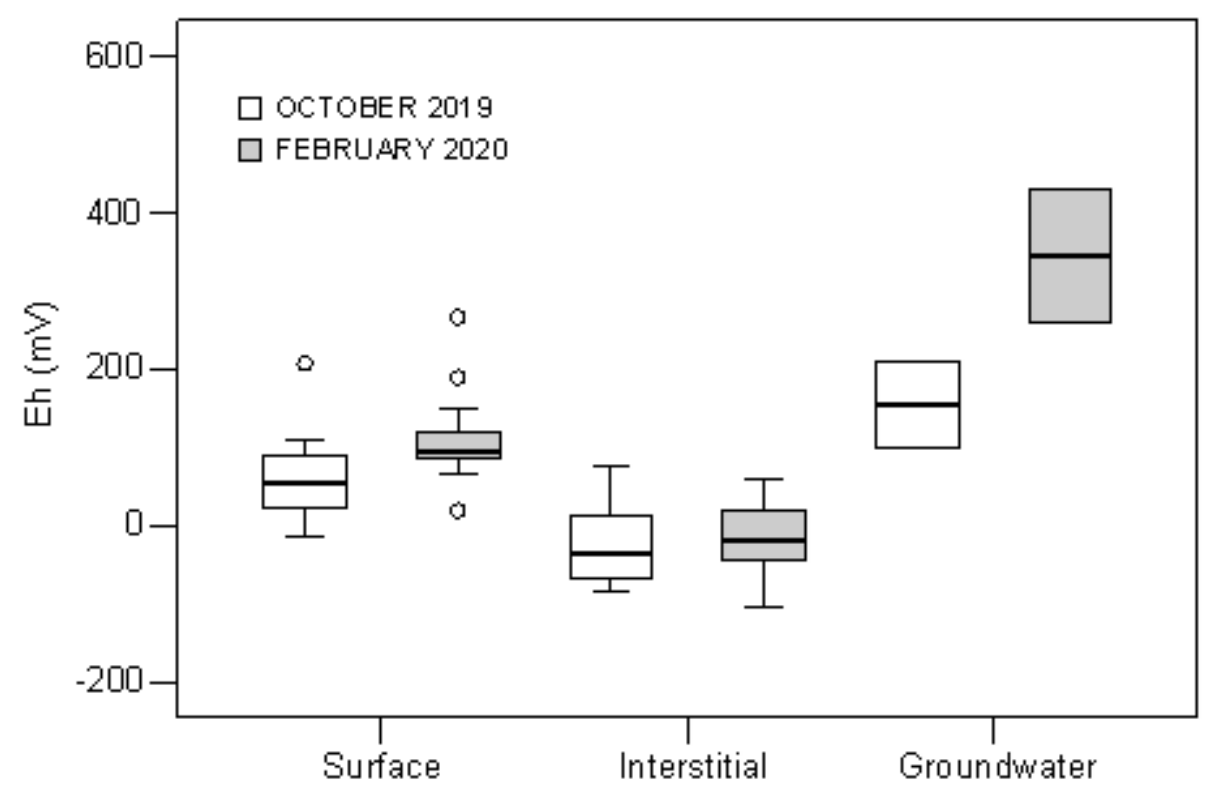

Figure 5

Box-plot of redox potential $(\mathrm{mV})$ in surface, interstitial and groundwater in the tropical karstic marsh La Esperanza, Quintana Roo, México.

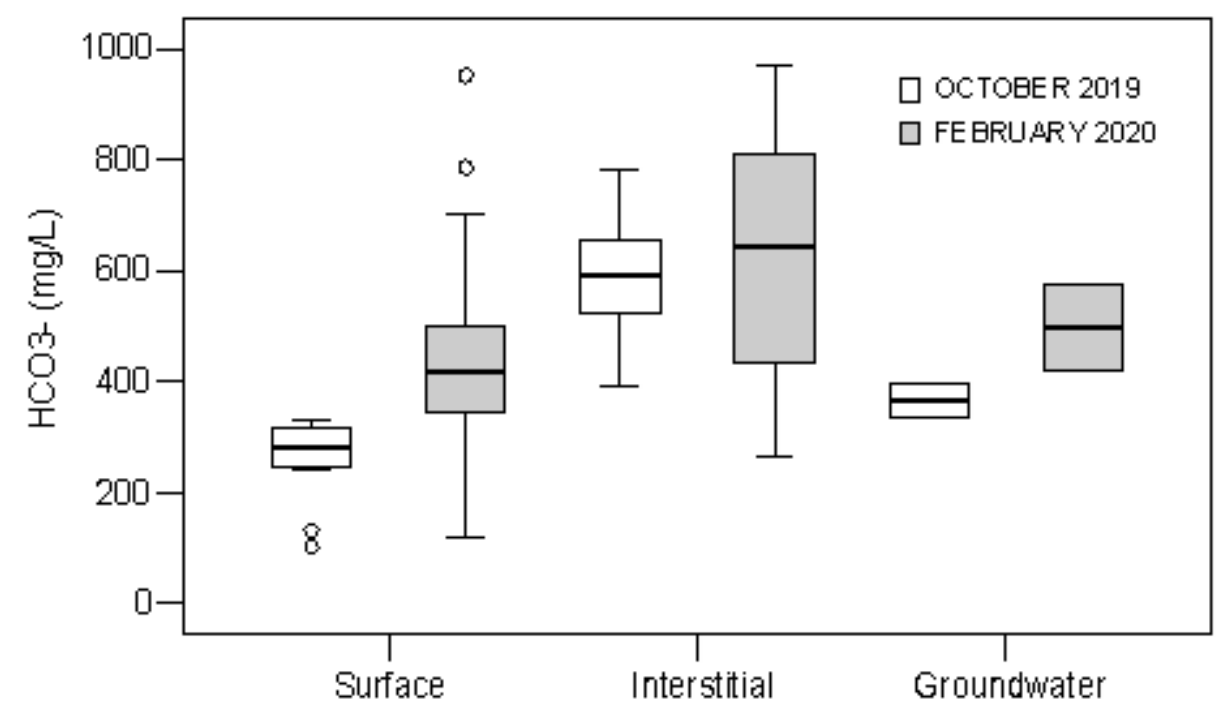

Figure 6

Box-plot of bicarbonates (mg HCO3-/L) (mV) in surface, interstitial and groundwater in the tropical karstic marsh La Esperanza, Quintana Roo, México. 


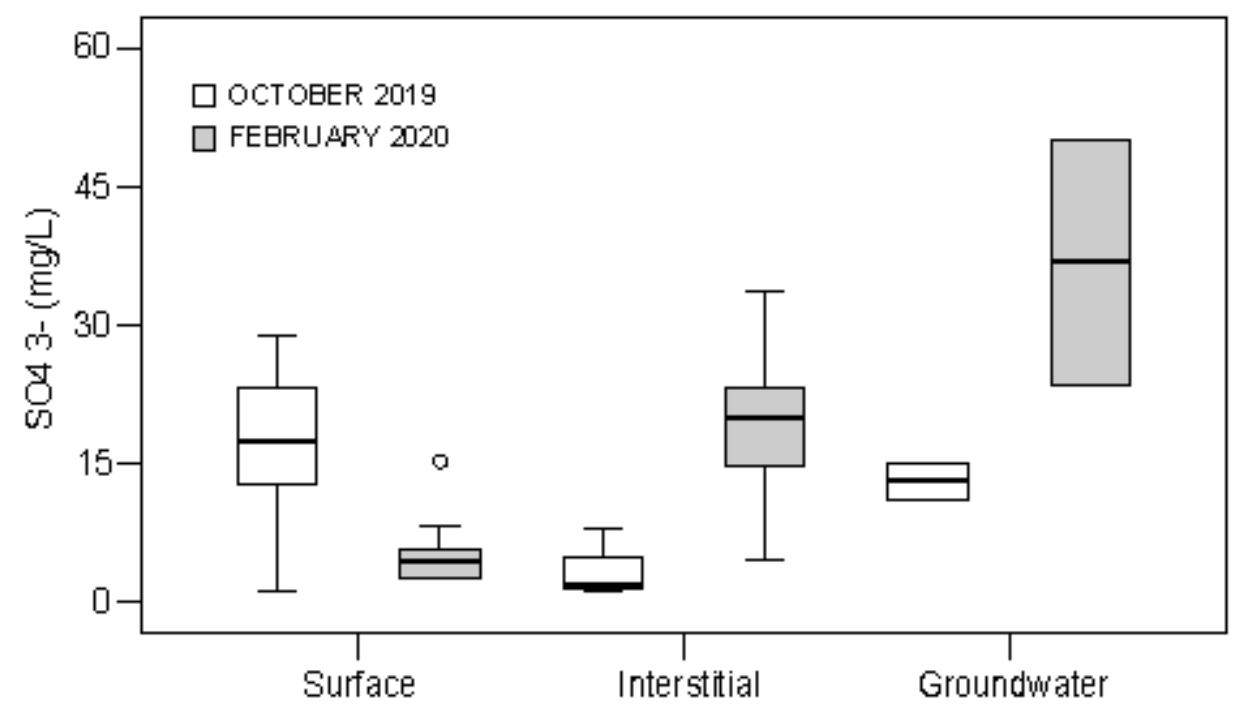

Figure 7

Box-plot of sulfates (mg S-SO43-/L) in surface, interstitial and groundwater in the tropical karstic marsh La Esperanza, Quintana Roo, México.

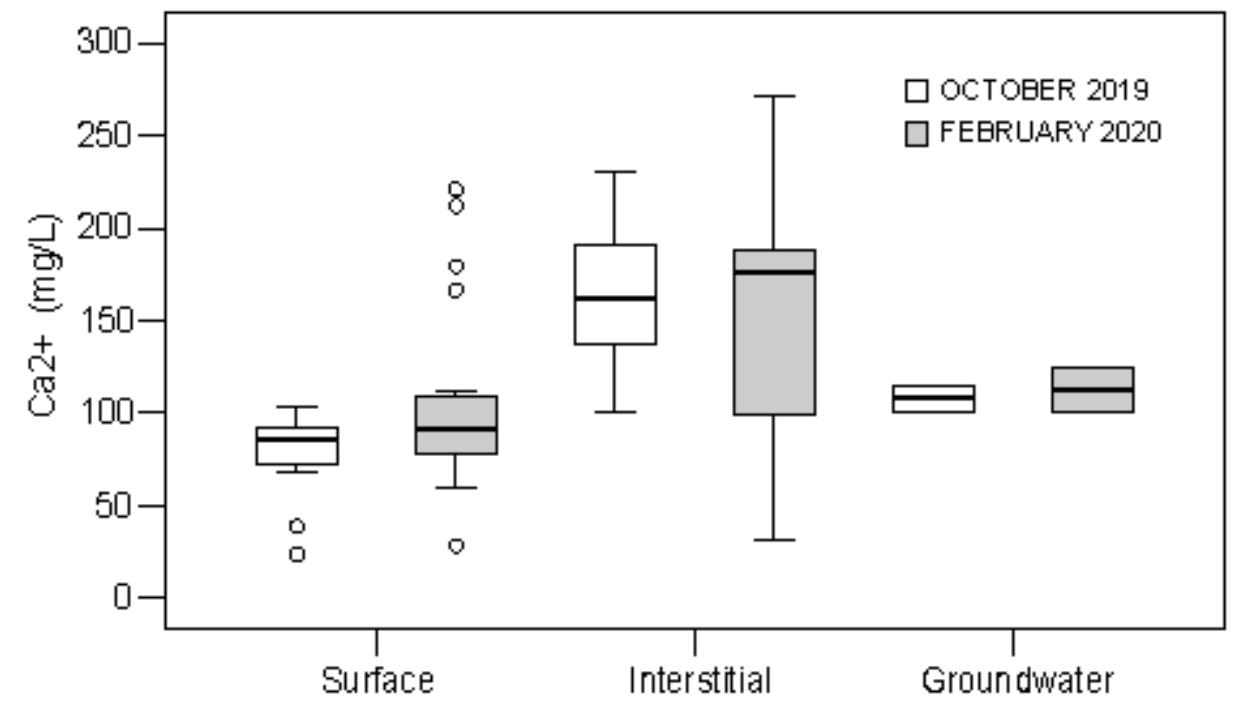

Figure 8

Box-plot of calcium (mg Ca2+/L) in surface, interstitial and groundwater in the tropical karstic marsh La Esperanza, Quintana Roo, México. 


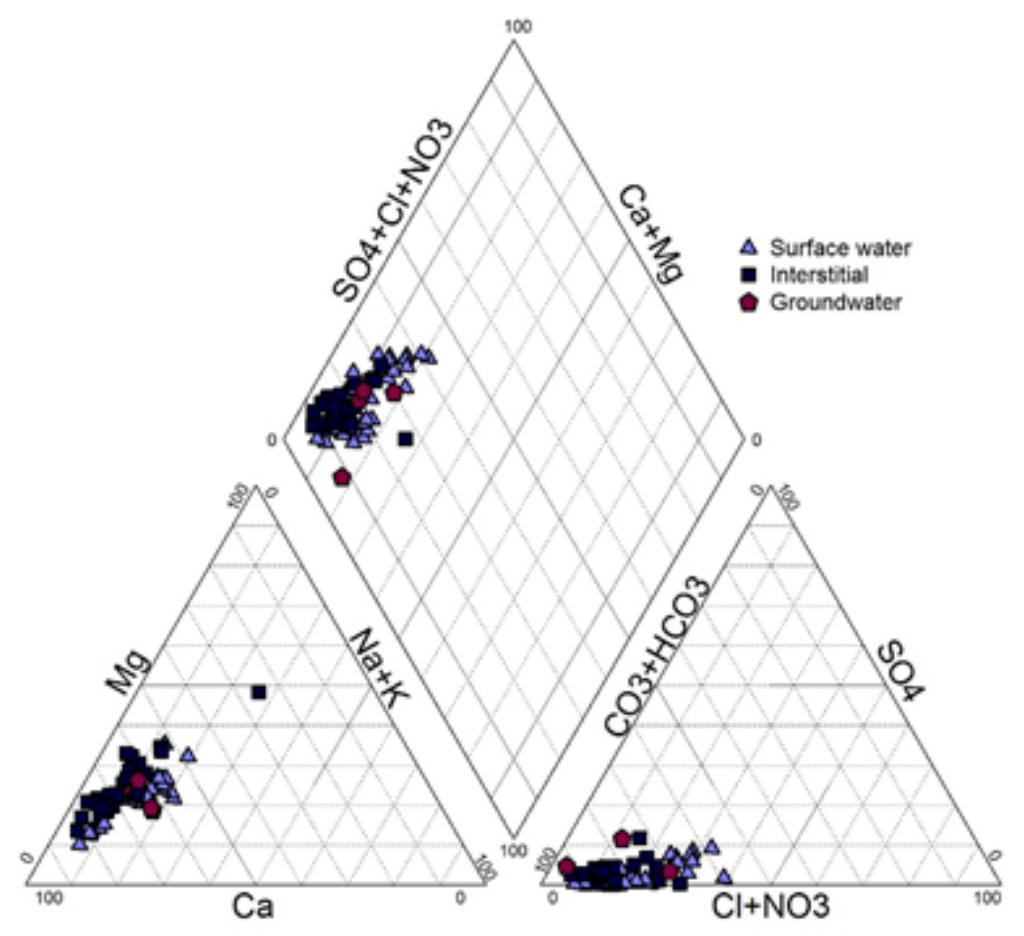

Figure 9

Piper diagram of surface, interstitial and groundwater in the tropical karstic marsh La Esperanza, Quintana Roo, México.
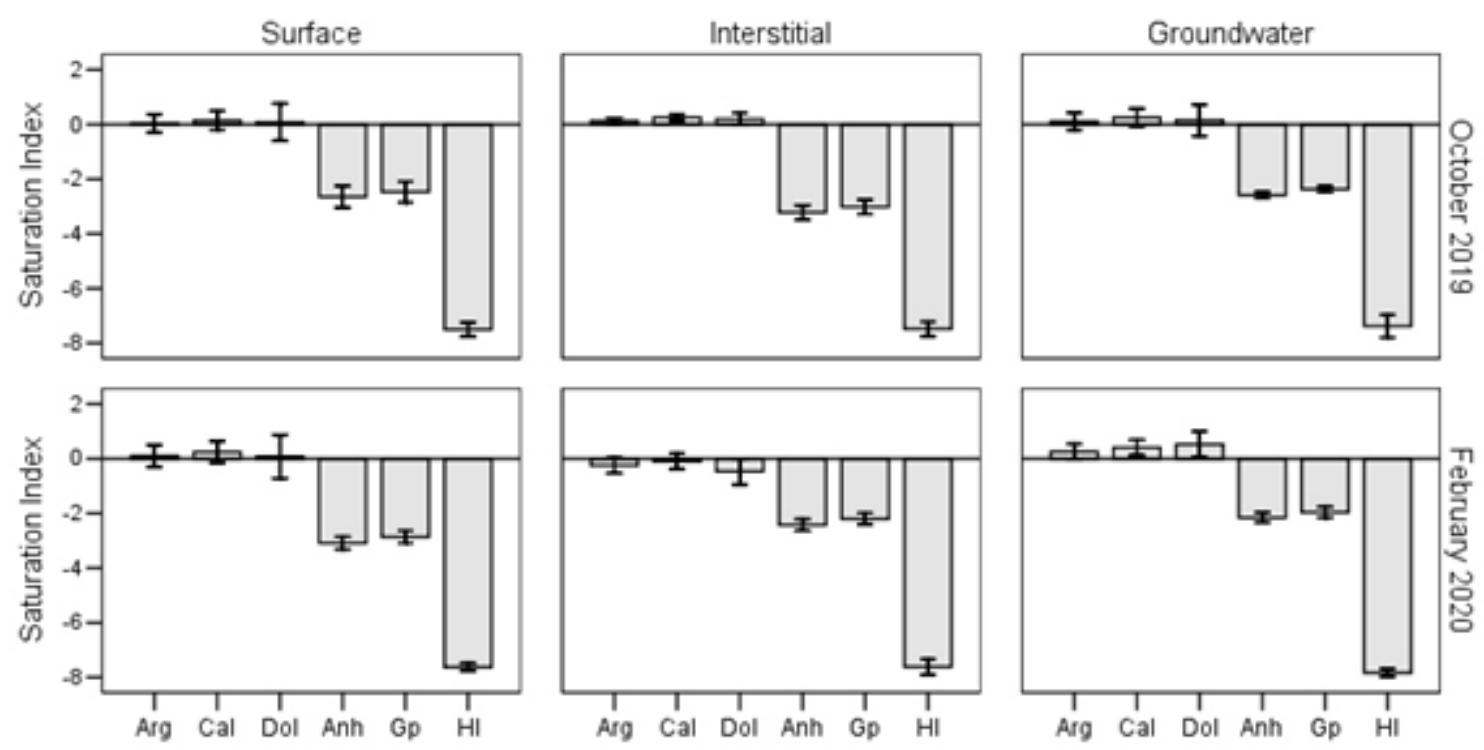

Figure 10 
Saturation index of minerals from surface, interstitial and groundwater in the tropical karstic marsh La Esperanza, Quintana Roo, México. Arg-aragonite, Cal-calcite, Dol-dolomite, Anh-anhydrite, Gp-gysum, HIhalite.

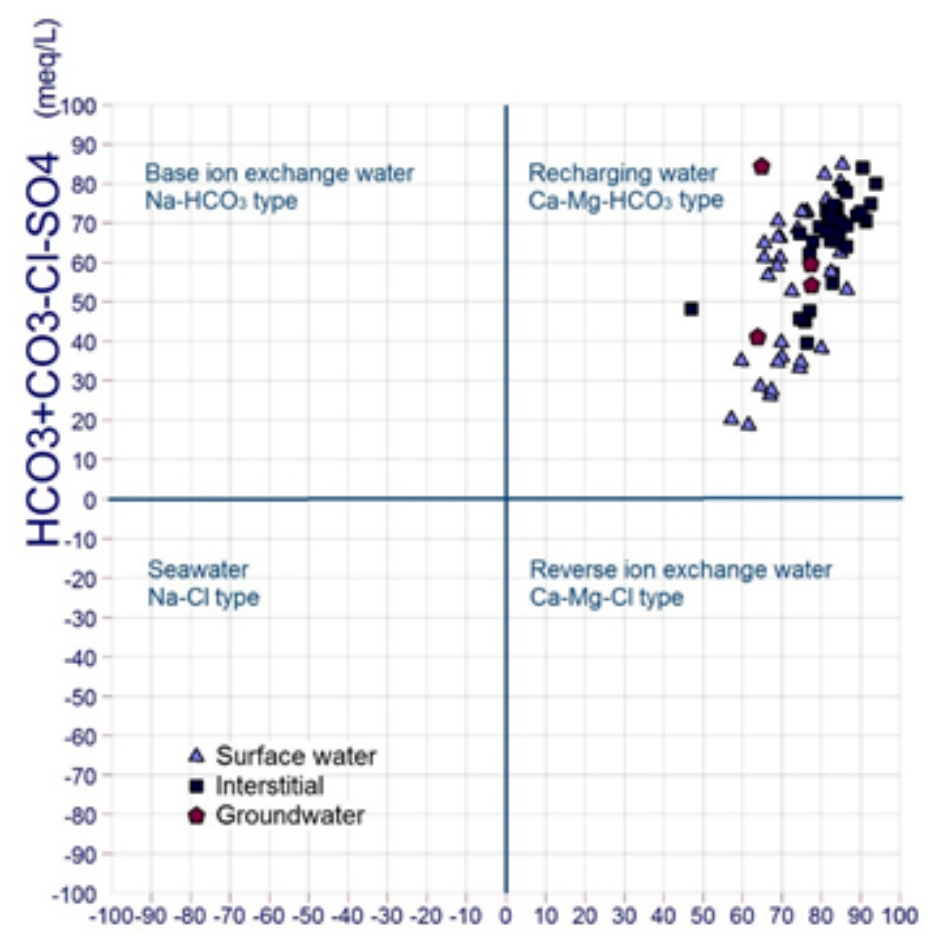

$\mathrm{Ca}+\mathrm{Mg}-\mathrm{Na}-\mathrm{K} \quad(\mathrm{meq} / \mathrm{L})$

\section{Figure 11}

Chadah diagram of surface, interstitial and groundwater in the tropical karstic marsh La Esperanza, Quintana Roo, México.

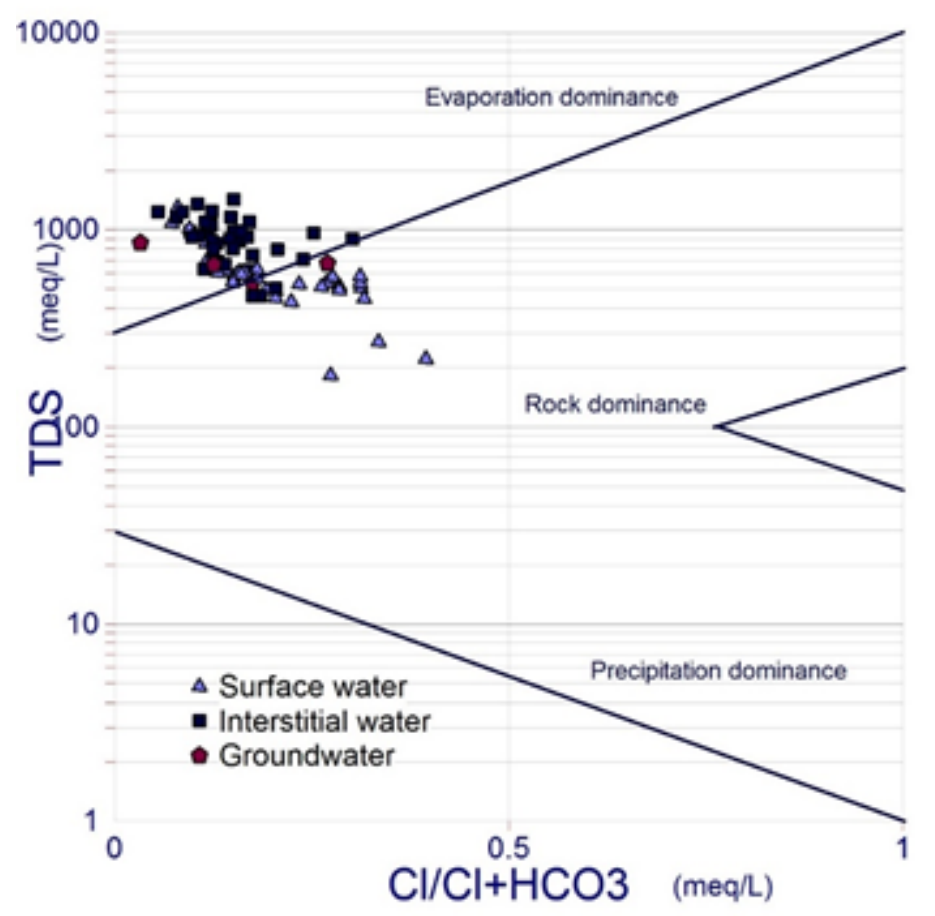


Figure 12

Gibbs diagram of surface, interstitial and groundwater in the tropical karstic marsh La Esperanza, Quintana Roo, México. 